\title{
Leadership Style: School Perspective in Cameroon
}

\author{
Asan Vernyuy Wirba \\ Department of Management and Information Technology (MIT), Juhail Industrial College, P.O. Box 10099, \\ Jubail Industrial City 31961, Saudi Arabia \\ Correspondence should be addressed to Asan Vernyuy Wirba; asanv5@yahoo.co.uk
}

Received 20 May 2015; Revised 20 August 2015; Accepted 2 September 2015

Academic Editor: Eddie Denessen

Copyright (C) 2015 Asan Vernyuy Wirba. This is an open access article distributed under the Creative Commons Attribution License, which permits unrestricted use, distribution, and reproduction in any medium, provided the original work is properly cited.

This paper examines leadership styles of secondary school principals in Cameroon, in terms of transformational, transactional, and laissez-faire leadership styles. This paper discusses the leadership styles in Cameroon and puts forward ideas for continuous improvement. A qualitative approach, using a semistructured interview, was adopted. It was conducted on ten principals, ten teachers, and ten students. Majority of respondents from schools described their principals as transformational leaders. Doubts are cast on the nature of transformational leadership in schools in Cameroon, since there is less training and development for leadership in schools.

\section{Introduction}

In Cameroon today there are two educational systems that have been in existence since independence. French or Francophone and English or Anglophone system of education both are run under colonial heritage. The French or Francophone is dominant in terms of population and size; 80 percent of the population speaks French, although Cameroon is a bilingual country. Ngefac [1] affirmed this fact by stating that the two official languages of Cameroon remain French and English but out of the ten provinces or regions eight speak French and only two speak English. He argues whether the strategy to implement bilingualism in Cameroon is fruitful. There are conflicts between the two systems of education on how best to lead or manage schools, and the Francophone, as the larger group, tends to dominate. For example, Ministerial Texts or Orders and school management guidelines are written in French without translation. Principals in both divides are working in difficult situations due to the fact that they are not trained in leadership to run their various schools. Recently there is a tremendous interest in the English Educational System from those born in the Francophone zone and having a French educational background. This trend is notable in larger cities, especially in Yaoundé, where many Anglophone schools are overwhelmed by the high demand from
Francophone parents. To this effect, Kouega [2] argued that choosing English and the Anglophone system of education by French speaking Cameroonians is because of unique advantage of the language. Achimbe [3] also ascertained that the demand for English education is not born of new positive attitudes toward English speaking Cameroonians but is instead an endeavour to benefit from the advantages related to English proficiency.

The Anglophone or English and Francophone education systems are closely modelled along the lines of colonial heritage. The challenge posed to principals running these schools and the government is to have greater harmonisation of the two systems of education and also do translation of government document into two of the national languages. Harmonisation of the two systems proves challenging, since each side of the equation wants to maintain its own traditions, colonial heritage, and culture. To this effect Tchombe [4, p.10] argues the following.

During the early independence years, the country had a federal government whereby each system of education maintained its own colonial culture. The French more than the Germans had a highly centralised administration. But the British allowed some degree of autonomy. 
The centralised (French) and the decentralised (British) administrative procedures clearly illustrate a great difference between the British and French systems of education. Harmonisation of two such systems presents structural and organisational problems.

The above is the situation that principals of schools within the two systems of education are faced with as observed by Tchombe [4]. Within the rapidly expanding system of education, experienced educators and skilled senior classroom teachers are routinely appointed as principals to run complex school organisations.

Statement of the Problem. The speed at which classroom teachers are turned into principals shows the lack of emphasis on leadership training for current principals in schools in Cameroon. Leadership and managerial competencies are needed for principalship, rather than good teaching abilities or longevity alone. Long [5] attests to this fact and argues that applied knowledge alone does not constitute lawful administration training. Too many costly errors can happen while knowledge is being acquired and, in any case, the superiority of knowledge can vary extensively. Trial and error should not be a substitute for leadership skills and competencies training. Although prior practical experience is also needed, it is important and necessary that those who are to be principals in schools in Cameroon and elsewhere have to be trained in leadership and management skills. The fact that any teacher who graduates from an Ecole Normale Supérieur (Advanced Teachers Training College) (ENS) can become principal of a secondary school in Cameroon without much experience in leadership is an issue. The fact that teachers are offered a training course in administration during their training is not enough. They need more leadership and management competencies training. The importance of the principal's leadership is paramount as Leithwood and Reihl [6] emphasize that if you "Scrape the surface of an outstanding school...you will find an exceptional principal. Scratch or Peer into a deteriorating school and you will find a feeble leadership."

The Aim of the Paper. This paper is aimed at examining leadership styles of principals in schools in Cameroon in connection with transformational, transactional, and laissezfaire styles. In order to examine principal's leadership style, semistructured interviews were conducted to elicit more information from the respondents about principals leadership style. The need for semistructured interview for this paper is due to the fact that it would allow the respondent's principals, teachers, and students the freedom to express their views in their own term and that will yield more data to the paper. Also the need to conduct such interviews in Cameroon is due to the fact that there is less training and development of leadership in schools in Cameroon. Therefore, no matter what theory or style of leadership that is chosen as a starting point, the ideas are likely to be unfamiliar to the principals, teachers, and students. Trained teachers in schools in Cameroon can become principals at any given time without any leadership skills. In other words, when teachers graduate from their training schools to become teachers of various fields, they are equally sent to various schools to become principals. Since the transformational leadership style has been described as the "new leadership" paradigm by Bryman [7], it would seem to be an appropriate yardstick against which to view principal's behaviour in schools in Cameroon as a way forward. Also, since transformational leadership is seen by many as the contemporary method of leadership theory needed in schools, with rich literature, thus the important position of transformational leadership in the study of leadership in developed countries can be seen from research done by Barling et al. [8]; Bass [9]; and Dvir [10]. Interestingly, such writers argue that transformational leadership can be taught and learned. Schools in Cameroon may have to adapt or adopt and learn how to implement such a leadership approach when trying to improve the leadership of secondary school principals. This, among other things, is to ensure that the future appointment of principals does not result in a situation described by Nwankwo ([11], p71), where

\section{... a bad administrative leader may render inef- fective even the best school programme, the most adequate resources and the most motivated staff and students.}

Thus, leadership is very important to combine the achievement of the task, which is an organizational requirement and the satisfaction of employees, which is the human resource requirement [12].

To avoid such a situation noted above, there should be a mechanism in place to produce a rich vein of potential principals in Cameroon, armed with the current theories of leadership styles and management that have been practised and developed through special training institutions. This is because theory should inform practice. Bush [13] argues that theory remains a significant influence on practice. It should be noted in this paper that transformational leadership is not an end in itself, but rather a point of departure for the study of leadership in schools in Cameroon.

\section{Research Questions}

(1) What are leadership styles of principals in schools in Cameroon in relation to transformational, transactional, and laissez-faire leadership style typology?

(2) What are the differences of leadership styles of principals as perceived by principals and teachers in both public and private schools?

(3) What are student perceptions of the type of leadership their principal portrays?

\section{Literature Review}

This paper examines the literature drawn from both educational and noneducational settings. This is because much of the literature on education itself stems from noneducational settings. To this effect Hallinger and Snidvongs [14] argue that

Leadership preparation in the field of education has had a long and ambivalent relationship 
with the world of business management.... The pendulum has swung back and forth several times between education's embrace of business management techniques that would make schools more "efficient" and movements proposing that the profession should focus on developing leaders strongly grounded in education.

Thus, educational leadership or administration frequently borrows from business settings. However, when applying such leadership and management theories and practices from industry or business to education, caution should be exercised. This is because the two have distinct goals or purposes. The overriding goal of business enterprise is profitmaking, in contrast to education, whose purpose or goal is the cultural transmission and socialisation of cultural norms, which is difficult to measure. That does not mean that we should not learn from business; rather we should focus on leadership and management competencies which are relevant to schools today, especially when there is an increased call for greater accountability in education.

2.1. Reviews about Leadership. Scholars like De Pree [15] argue that "concepts of leadership, notions about leadership, and leadership practices are the topic of much assumed, discussion, writing, and learning." De Pree [15] believes that true leaders are sought after and cultivated. He goes on to argue that, ironically, the evidence of outstanding leadership manifests itself primarily among the followers and is not always something daily recognised in the leaders themselves. The same sentiment is expressed by Northouse [16] where leadership is a much desirable and highly respected service and businesses want individuals who have leadership skill, because they believe these individuals provide special assets for their business. Kotter [17] on the other hand attests to the fact that "Effective companies do not wait for leaders to come along, they vigorously pursue people with leadership potential and expose them to job skills designed to nurture their potential." Writers like James [18] argue that "in Britain and elsewhere, leadership in education has recently risen in eminence." His main argument is that the number of texts and papers where leadership is prominent has increased significantly in the last five years. James cited several examples (Ribbins 1997; MacBeath 1998; Strain, Dennison, Ouston and Hall 1999; Leithwood, Jantzi and Steinbach 1999) and concluded that leadership features significantly in recent British policy developments (DfEE 1998; DfEE 1999; TTA 1998) [18]. He therefore attests to the fact that this era is the era of educational leadership.

According to Leithwood [19], the kind of leadership needed to bring change to the organisation is transformational leadership. Let us hope that this is not a fad that will came and go like others. Yukl [20], on the other hand, holds the view that leadership occurs when one person in a group stands out and leads the others, who are then referred to as followers or subordinates.

This paper examines leadership in schools in Cameroon from a transformational, transactional, and laissez-faire leadership perspective as a foundation for practical application in the future. According to Nkata [21], educational practitioners have recognized leadership as vitally important for education institutions, since it is the engine of survival for the institutions. This recognition has come at a time when the challenges of education development worldwide are more demanding than ever before. The same could be said for Cameroon schools, whereby there is a rapid growth in educational institutions and increasing enrolment will necessitate good leadership and management of its schools. Lambert [22] argued that the influence of school leadership and management on teachers' attitudes to their jobs is that there is a positive relationship between teacher morale, job satisfaction and motivation on the type of leadership in schools (ibid). Indeed, head teachers have the capacity to make teachers' working lives so unpleasant, unfulfilling, problematic, and frustrating such that they become the overriding reason of why some teachers do not perform as expected and some have to exit the profession. She cited one quote from her interview of a teacher who has this to say about her principal or head teacher: "I do not know what it is about her, but she made you want to do your best and not just for her, but for yourself ... You are not working to please her, but she suddenly made you realize what was is possible, and you, kind of, raised your game."

Thus, it is importance to adopt and analysis different leadership style that can improve school performance.

\subsection{The Three Styles Reviewed for This Paper Are as Follows}

2.2.1. Laissez-Faire Leadership Style. The laissez-faire style is also known as the hands-off style of leadership. This style of a leader exercises little control over his followers. Laissez-faire leaders abandon their responsibility, delay decisions, give no feedback, and make little effort to help followers satisfy their needs. There is no exchange with followers or any attempt to help them to grow. Laissez-faire leaders make little personal contact with workers in their organisations.

2.2.2. Transformational Leadership Theory. The transformational leadership theory emerges as responding to the shortcoming of traditional leadership theories. This theory suggests that effective leaders produce and promote a desirable vision or image of the organisation or institution. The transformational leaders should encourage their institutions to accept change. Oyetunyi [23] argues that the transformational leadership focuses on diverse kinds of leader's influence that inspire followers to develop as leaders. They create organisational circumstances in which followers can develop their own leadership capabilities. Rowe [24] also argues that transformational leadership focuses on developing the organisation ability to innovate. Rather than focusing precisely on direct coordination, control, and supervision of the curriculum and instruction, transformational leadership seeks to build the organisation's ability to select its purpose and to support the development of changes to practices of teaching and learning. The studies done by Leithwood et al. [25] give us strong evidence or support the fact that transformational leadership is a key factor in facilitating a positive school culture. 
2.2.3. Transactional Leadership Theory. The transactional leadership theory differs from the transformational leadership theory in which the transactional leaders do not individualize the needs of the followers or focus on their personal development. The transactional leaders exchange things for value with the followers to advance their own and followers interest or needs. Haven reviewed the theories of leadership; it is obvious that theories of leadership have evolved. The earlier theories of leadership tended to focus on the characteristics and behaviour of successful leaders, while later ones started to consider the role of the followers and the contextual nature of leadership; others tended to focus on transformational and transactional leadership.

\section{Methodology}

This paper involves an analysis of a semistructured interview with ten principals and ten teachers in both public and private schools in Cameroon and also ten student views with regard to their principal's leadership styles.

The purpose of the semistructured interviews in this paper was to collect interview data from the respondents with regard to current principal leadership styles in Cameroon. As noted above ten school principals were selected, ten teachers, and ten students and student leaders, using purposive sampling techniques. In using this technique I made sure that everyone in the population has an equal chance of being selected as a respondent. I was able to be prepared ahead of time. This among other things enables me to appear competent during the interviews and at the same time allows my respondents the freedom to express their views in their own term. Thus, by using the semistructured interview for this paper I was able to observe and develop a keen understanding of the topic and at the same time have the opportunity to tape record interviews and later transcript these tapes for analysis.

3.1. Data Collection. The data collected from this semiinterview with principals, teachers, and students was procured from face-to-face interactions with the respondents. Principals, ten teachers, and students were asked to respond to some semistructured interview questions about their principal's leadership styles. The duration of each interview was approximately 30-45 minutes and all were tape-recorded.

3.2. Interview Procedures. The respondents were briefed on the general nature of the research and how the interviews were going to be done and also issues of confidentiality and how information gathered would contribute to the paper. Semistructured interview questions were used with respondents and they were asked for their responses. I selected ten principals, ten teachers, and ten students from schools in Cameroon. The selection of these respondents was based on their knowledge and their experiences as principals, teachers, and students who had been in their various schools for at least two years or more and they can best describe their principals. A snowball purposive sampling technique was used because these respondents knew their principals better. I contacted these principals and teachers as well as students before interviews. As the interview developed, there was a movement away from semistructured questions. This task was performed while the tape recorder was switched on, to record all information and responses given by the respondents.

3.3. Data Transcript and Analysis. The data for this paper was completed in secondary schools in Cameroon which yielded a large amount of interview data in the form of field notes and tape recordings. During the interviews a large volume of interview data was organised into smaller units or categories of information, to make sense of it. The writing up of the data from interviews was done immediately after finishing the interviews. This was necessary, so that the recollection of the events in the field would still be vivid. I would have time to reflect when analysing them. I transcribed the interviews, and after reading them carefully I decided to look for patterns in the responses. Then these patterns were separated into key concepts or themes that were subsequently used to analyse the interview data for this paper surrounding principal leadership styles or behaviours. The transcripts of the interviews clearly show how I conducted the interviews with the relevant questions asked during the interviews and their subsequent answers, either from the principals themselves or from other members of various school communities, that is, teachers and students.

3.4. Analysis of Qualitative Data. In the process of analysing data from the transcripts demographic variables were also taken into account, as presented in the following.

3.5. Demographic Variables. The demographic characteristics of principals in this paper varied, but all were male, despite the fact that there were two female principals in nonpublic schools in Cameroon, whom I wanted to interview. I made several attempts to interview these two female principals but failed. It is my conviction that these two female principals are important role models for the girls in these various institutions. I am sure that many female students are inspired by them, not least because of their small numbers in such an important position in schools in the Province. Unfortunately, I did not interview them to have their perspective as to what leadership style best describes them. This could be due to the fact that, due to their small numbers, they are occupied with other duties of home and education.

All the principals and teachers as well as students of these schools interviewed have been in their various schools for more than one year as staff or students. They have been long enough in their schools to know their principal and are in the best position to describe their leadership style. Of course, the majority had been there for much longer. In fact, most of them know each other personally and have established a good professional working relationship and are therefore in a good position to describe the leadership styles of their principals. As I went to interview the principals, it was made clear that there is no formal training to become a principal in secondary schools in Cameroon. A teacher who graduates from their various fields of study, for example French, English, mathematics, geography, or history teachers 
can expect to be appointed as principle at some point in their career, whether it is for skill as a teacher or longevity of service. To this effect Dadey and Harber [26] argue that the fault of school leadership is often reinforced by the apparatuses for the choice of school principals. The leading practice has been to recruit principals from within the teaching occupation, often as a payment for good performance, extensive years of service, or political compatibility with the prevailing political alignment of the regime. Possibly, there is a critical need for criteria which are based on sound professional training. During the interview it was made clear to me by all of the principals interviewed that they had had no formal training to become principal. They were only trained as teachers of their different disciplines. Thus, long serving teachers, experienced and inexperienced teachers, good teachers, and vice principals are made principals, although there is no guarantee that being a good teacher or having a long service makes a good principal without professional training. I also discovered during the interviews that there were no clear criteria used in the appointment of principals, which led to some staff questioning promotion decisions and a feeling that some promotional posts were filled on the basis of political ideology or affiliations, something quite common in developing countries. In short, it seemed that practically any one could be appointed as a principal of a school, provided that they had been trained as a teacher and were politically "acceptable."

3.6. Analysis of Qualitative Data. In trying to understand the principals' leadership styles in secondary schools in Cameroon, I started by asking principals what they perceived as their major role and duties in their various schools, their constraint, and their perception of a good leader in schools although this was the major question in the paper. They have the following to say.

Principal's Thinking about Their Roles and Duties. Typical comments on the mix of responsibilities are as follows:

\section{Taking care of the personnel and communicating to the government about the nature of the school, and also the relationship with parents of the school and the community at large. Ensure good relationships with all the stakeholders for the smooth running of the school. (Principal) \\ Coordinator of all activities of the school and represent school in all external affairs and ensure the smooth running of the school. (Principal)}

In summary, principals view their duties differently, although all mention coordination as important. Some see their duties as acting as a link between the school and the outside world. Having said the above, it is possible that the lack of formal training might have contributed to their different opinions about priorities. Thus, the lack of leadership development of principals may mean some are insufficiently clear about their roles and duties. Their difference in understanding of job functions is clear and necessitates professional training in order for all principals to uniformly understand roles and responsibilities.

Constraints. Many constraints affect the work of principals, including lack of formal training in leadership and management. To name a few, there are lack of financial resources, lack of qualified teachers, poor salaries, lack of computers to computerise records, overcentralisation, poor quality buildings, little funding for professional development, no school transport, no telephones in schools to contact parents, lack of reading materials, bookshops and libraries in schools, and untrained librarians where libraries do exist. It is clear that a leader cannot function well with such limitations. This means that principal may have the desire to carry out his or her functions well, but these constraints prevent him or her from achieving his or her aims. The complex and fragile nature of the job are testified by the following comments:

There is over centralisation and if you have a problem, it has to be solved from Yaoundé, the capital of Cameroon very far from the Provincial and Divisional levels. At a certain level, you have problems and if you go to the Provincial or Divisional level they will send you to the hierarchy. Thus, it takes time to solve such problems especially when it comes to disciplining a recalcitrant teacher it is always very difficult. Also some teachers are posted to schools without being paid. For example, newly graduated teachers who are posted without salaries they keep on moving up and down chasing their documents in the ministries so that they can get paid which is demotivating for the staff concern and the school the teacher is posted to who cannot do anything. (Principals)

Clearly, there are many constraints upon the work of principals in schools in Cameroon. These constraints are compounded by large school classes lacking basic equipment and a slow pace of change in the system, which seems to be getting worse rather than better. The above constraints have a relationship with government IMF adjustment policy which hit the educational setting in Cameroon hard. The overcentralisation of education decision-making in Cameroon is having a negative effect as far as newly appointed teachers are concerned. New teachers have to start chasing their documents at various ministerial levels, most of which are salaryrelated. Due to lack of coordination between ministries, it may take one or two years for a newly appointed teacher to get their first pay, which is inconceivable but true for Cameroon. Newly appointed teachers spend one to two years travelling in and out of Yaoundé trying to be paid for work performed.

Principals' Perception of a Good Leader. In this paper, I discovered that the principals of secondary schools in Cameroon expressed a number of common views as to the qualities which, they believe, make an effective leader. The majority of them believe that a good leader should exhibit the ability to manage family life and professional tasks, defer to a more qualified person in discussion, have the ability to mediate 
between the external and the internal pressures, show bravery in tackling sensitive decisions, and show respect for all staff and students, in addition to being honest, moral, polite, and persuasive.

Such observations by principals have been variously expressed in the following:

The ability to work in harmony with a disciplined labour force, respect for human dignity, honesty, bravery and the propensity to stick to the core of Islamic values and beliefs to produce responsible moral individual for the society. (Principal)

A good leader should be righteous, flexible, and humble with good morals where interest is based from within through encouragement, inspiration, motivation and persuasion. Moreover, he should possess that wisdom to blend external influence to cohabit with internal imperatives. (Principal)

The principals' perceptions of a good leader seem to be rooted in his/her ability to work in harmony with a disciplined labour force, respect, honesty, bravery, and the propensity to stick to the core values and beliefs to produce responsible moral individuals for society. The above is reflected in the review of the literature for this paper. The global leadership studies view honesty as the most important value of transformational leadership, with bravery also seen as an important trait in the theory of leadership. Some of these principals interviewed have the view that managing professional life should reflect home life. One can deduce from the above comment from the principals that they are humble, and some may have been influenced by their religious beliefs. Some principals represented are priests who also teach. These principals live in a culture where those in authority are not challenged. This occurs for many reasons, for example, a fear of reprisal or a lack of other opportunities in other careers. Therefore, people have to conform to exist. No one would like to jeopardise his/her job or to be sent to areas where they do not want to go because of their attitudes toward authority. This does not mean that there are no people who will speak their mind; there are, but often at a personal cost. Personal attributes manifest themselves when looking at the responses from these respondents. Many aspects of trait theory are manifested in these responses, for example, being brave, honest, and disciplined.

What Are Leadership Styles of Principals in Schools in Cameroon in relation to Transformational, Transactional, and Laissez-Faire Leadership Style Typology? The above reflects question one of the research questions. However, during the interview I read these leadership styles and asked principals and teachers to choose which best described their principal and the principals themselves. All principals choose transformational leadership. Some of the teachers view their principals as transactional leadership as well as coaches. I am not quite convinced with the principal's choice of describing themselves as transformational leaders. I think if the interview question had been structured differently, the outcome could have been different. Perhaps a more thorough explanation of the various leadership styles as they applied to schools (transactional, transformational, and laissez-faire leadership style) could have been offered. The rationale for identifying principals' leadership styles stems from the fact that once those leadership styles are identified, proper recommendations could be made regarding training for improvement. The statement made by Beare et al. [27] sums up the assertion of this paper and it aims to promote good leadership in school in Cameroon. There is no doubt that seeking excellence in education must ensure the presence of the development of potential leaders as urgency. In seeking an answer to research question one, I believe that those who work closely with the principals on a day-to-day basis are more likely to be able to describe the leadership styles of their principals. As noted above all principals interviewed described themselves as predominantly transformational leaders. When trying to examine these key aspects of transformational leadership as perceived by teachers, there was evidence of elements of power and competence. Some teachers view their principals as coaches who try to teach and inform them. I cannot conclude from the above that principals in secondary schools are transformational leaders. What we can, however, learn from this paper is that teachers perceived that principals act as coaches or guides for teachers on what they do not know but sometimes they exercise their positional powers on them if they do not do as required. The other aspect is that some teachers and students see their principals as being democratic. It may be that they are describing what they could become if given the time and training, for example, a more aspirational view of their leadership styles. There is no evidence to suggest that such a style of leadership is being practiced, but rather a hope is given that this someday might be the case. In an environment where there is less emphasis on leadership, I doubt whether the principals' description of themselves as transformational leaders is accurate.

What Are the Differences of Leadership Styles of Principals as Perceived by Principals and Teachers in Both Public and Private Schools? Research question two stems from the need to understand the differences between the leadership style of principals in public and nonpublic schools. Are there differences between public and nonpublic schools in leadership styles? This result shows that both principals from public and nonpublic schools best describe themselves as transformational leaders, with the exception of one teacher in the public school who best described their principal as a transactional or a democratic leader. This also is reflected on research question one.

What Are Student Perceptions of the Type of Leadership Their Principal Portrays? This is to answer research question three. In other words to answer this research question I interviewed the students to find out who they think is the leader in their school.

Students' Perception of Who Is the Leader in Their School. During the interviews for this paper, students had this to say as to whom they perceive to be the leader of their various schools: 
Our principal is the leader of the school. He leads with his vice and other administrative staff of the school. In fact, I can say that they work as a team. That is why in my mind, the school is performing positively at Certificate Exams and our school is the envy of other schools in the community. (Student)

The principal is the leader of the school and at the same time a teacher, he don't only lead but he teaches us in preparing for our final national examination. (Student)

Students perceive their principals to be leaders of their various schools. They also note that leadership is enhanced by principal collaboration with other staff and student leaders. They view some of their principals as team leaders who lead by example.

What Are Student Perceptions of the Type of Leadership Their Principal Portrays? These answers varied and during the interviews, students had the following to say of their principals:

\begin{abstract}
He is an honest man, and transparent in his dealing with us as students, and with me in particular as a senior student leader which is refreshing and I hope to learn from him a great deal. (Student)
\end{abstract}

He is a family man; he is just like a father to all of us here and we appreciate that. He persuades his followers to always do well and by doing so our school is progressing in every aspect most importantly our national examination result are great. And that we have come here to learn and to succeed in our endeavours to be good citizens as well as future leaders. (Student)

The students interviewed perceive the leadership of their principals as moral, honest, and transparent. To some, their principals are like father figures: men of great integrity and also easy to approach and talk to, inspiring their students to work hard toward their academic achievement. They view their principal as being democratic. The democratic leadership style is reflected in the literature for this study as one of the leadership styles. I have already reported what the principals, teachers, and students said about themselves and about their principals. These results show variations in what they perceived as their roles, duties, and the constraints. From this result, it seems there is a need for formal training, to avoid the trial and error approach common among principals. In my view, there is a willingness to learn and improve from these principals. The government and private institutions should seize the moment and make sure they give these principals the tools they need to do their jobs, in addition to a good salary. In addition, public and private institutions should work toward creating an environment conducive to school leaders expressing their opinions without fear or favour. The results show that principals are yearning for leadership and management practices skill training in their various schools, bearing in mind that there is less training and development for leadership in Cameroonian schools. Evidence of this is provided by the variation of how principals describe their role in schools. They seem not to have a sound understanding about what their roles are. It is not astonishing in an environment where the authority relies heavily on senior classroom teachers for appointment as principals.

In this paper, I set out some research questions to answer, with question one being related to the leadership style that best described principals of secondary schools in Cameroon. The transformational, transactional, and laissezfaire typology was used as a starting point. The interviews conducted in secondary schools in Cameroon suggest there is an illusion of transformational leadership, rather than a reality. Some responses show there is a strong transactional, democratic element in principal-teacher relationship. The interviews that were conducted to explore the leadership style of principals in schools are seen as the beginning of a dialogue with school leaders about their practice and perceptions.

Theories should guide principals of schools in Cameroon, not trial and error and the subsequent use of "common sense." These trials and "common sense" policies guide principals, but they have no theoretical basis for decisionmaking. Theoretical base is crucial so that whenever common sense is used, it has its origin in theory rather than trial and error. There is a need for these principals to be guided by theories and leadership techniques and skills that could enhance their potential. This can be achieved through the creation of institutions whereby they could be trained in leadership theories, techniques, and skills necessary to lead as principals of Cameroonian schools. During the interviews, I observed some aspects of trust and honesty which is an aspect of transformational leadership as advocated by Den Hartog et al. [28], but these aspects needed to be there through some form of informed guidance and guided theories as I have argued throughout this paper.

\section{Findings from the Interviews}

(i) Principals in both public and nonpublic schools had no formal training in leadership prior to their appointment as principal. They were all trained as teachers in their various field of studies and, in some cases, some of them served as vice principals or discipline masters as well as head of various departments.

(ii) Principals are appointed and not elected, but there are no clear criteria for appointing them. The lack of clear criteria led to some feeling that appointment might have been politically engineered. Good classroom teachers are appointed as principals without training or clear criteria from the government.

(iii) All principals perceived themselves as transformational leaders.

(iv) Almost all teachers' best described their principals as transformational leaders except for one teacher in a public school who best described his/her principal as a transactional as well as democratic leader. One 
teacher from one public school differs in his/her view of principal leadership style.

(v) All the students interviewed best described their principals as being honest, trustworthy, and parental.

There is doubt to the nature of transformational leaders as perceived by principals as well as teachers although Den Hartog et al. [28] argue that some aspects of transformational leadership are universal in nature.

It can only be anticipated that principals are indeed doing their best in the job. These principals are being appointed from within the ranks of senior classroom teachers with little or no preparation for the complex task of school headship; it is surprising that they have achieved any success at all. They deserve more for what they have achieved on the basis of no training. Longevity and being a good teacher do not guarantee good leadership.

\section{Discussion}

In this paper, principals described themselves as good leaders which are rooted in the great man theory as being born to lead. The other aspect which came into light when interviewing principals with regard to good leadership is that a good leader rooted in his/her ability to work in harmony with a disciplined labour force, respect, honesty, bravery, and the propensity to stick to the core values and beliefs to produce responsible moral individuals for society. The global leadership studies view honesty as the most important value of transformational leadership, with bravery also seen as an important trait in the theory of leadership.

Transactional leadership theory is evidence when principals reward teachers for achievement, especially in academic activities. The leadership appeared as transformational when principals talked about the vision for their schools. Some teachers perceived that principals act as coaches or guides for teachers on what they do not know, but sometimes they exercise their positional powers on them if they do not do as required. The other aspect is that some teachers and students see their principals as being democratic. There is no single description of principals but majority turn to describe them as transformational leaders.

The above discussion in relation to theory and practice from both spectrums of leadership theory in schools in Cameroon is encouraging; however, there is little evidence of knowledge of theoretical bases that informed practice among principals. There is no formal training for leadership and management skills in schools in Cameroon; thus, there is less training and development for school principals in Cameroon. Many principals are not equipped with the current leadership theories to help them in their practices. Therefore, there is a need to address these issues or use current teacher institutions to train those who want to be principals with leadership and management skills.

Although this paper focused on transformational, transactional, and laissez-faire leadership styles as a point of departure, there is no best leadership style. No single description of the above theory could capture the full range of behavior of any one principal. This because principals are flexible, sometimes democratic, and sometimes autocratic. They may choose the style that suits the people at a certain time or situation. Therefore, there is no one best style. That being said, theory should inform practice.

\section{Conclusion}

The government and the private sector in Cameroon should undertake a leading role in creating institutions and various programs to train principals as leaders of their various schools. They should not rely on long serving teachers, good teachers, and senior classroom teachers, or vice principals to run complex schools in Cameroon. Data from the interview show that principals are not trained in leadership and management competencies. Although during the interviews they all described themselves as transformational leaders, teachers also almost described their principals as transformational leader except one teacher from a public school who viewed the principal as being transactional or democratic while the student view their principals as honest men and fatherly figures to them. They are only appointed as principals of their various schools based on long serving as a teacher, good teacher, or senior classroom teacher or even political affiliation. There is less training and development of principals in school in Cameroon. Thus, there is a need for current techniques in leadership and management skills for principals in both public and private schools in Cameroon as a way forward for continuous improvement.

\section{Conflict of Interests}

The author declares that there is no conflict of interests regarding the publication of this paper.

\section{References}

[1] A. Ngefac, "Linguistic Choices in Postcolonial Multiligual Cameroon," Nordic Journal of African Studies, vol. 19, no. 3, pp. 149-164, 2010.

[2] J. P. Kouega, "Forty years of official bilingualism in Cameroon: an appraisal," English Today, vol. 15, no. 4, pp. 38-43, 1999.

[3] A. E. Achimbe, "Linguabridity: redefining Linguistic identities among children in urban areas," in Linguistic Identity in Postcolonial Multilingual Spaces, A. E. Achimbe, Ed., pp. 66-86, 2007.

[4] T. M. Tchombe, Structural Reforms in Education in Cameroon, School of Education, University of Yaoundé, Yaoundé, Cameroon, 2001.

[5] R. Long, Management of Large Secondary Schools in Trends in Education, HMSO, London, UK, 1969.

[6] K. A. Leithwood and C. Riehl, What We Know about Successful School Leadership, Laboratory for Student Success, Temple University, Philadelphia, Pa, USA, 2003.

[7] A. Bryman, Charisma and Leadership in Organization, SAGE Publications, London, UK, 1992.

[8] J. Barling, T. Weber, and E. K. Kelloway, "Effects of transformational leadership training on attitudinal and financial outcomes: a field experiment," Journal of Applied Psychology, vol. 81, no. 6, pp. 827-832, 1996. 
[9] B. M. Bass, Transformational Leadership: Industrial, Military and Educational Impact, Lawrence Erlbaum Associates, Mahwah, NJ, USA, 1998.

[10] T. Dvir, The impact of transformational leadership training on follower development and performance: a field experiment [Ph.D. thesis], Economic Overview on Cameroon, Tel Aviv, Israel, 1998.

[11] J. I. Nwankwo, Educational Administration-Theory and Practice, Vikas, New delhi, India, 1982.

[12] J. A. Okumbe, Educational Management: Theory \& Practice, Nairobi University Press, Nairobi, Kenya, 1998.

[13] T. Bush, Theories of Educational Leadership and Management, SAGE Publications, London, UK, 2005.

[14] P. Hallinger and K. Snidvongs, Adding Value to School Leadership and Management: A Review of Trends in the Development of Managers in the Education and Business Sectors, National College for School Leadership, Nottingham, UK, 2005.

[15] M. De Pree, Leadership is an Art, Dell Publishing, New York, NY, USA, 1989.

[16] P. G. Northouse, Leadership: Theory and Practice, SAGE Publications, London, UK, 1997.

[17] J. P. Kotter, "What leaders really do," Harvard Business Review, vol. 68, no. 3, pp. 103-111, 1990.

[18] C. James, "The era of educational leadership: leadership times and leadership themes," in Proceedings of the BEMAS Annual Conference, Manchester, UK, September 1999.

[19] K. Leithwood, "Contributions of transformational leadership to school restructuring," in Proceedings of the Annual Meeting of the University Council for Educational Administration, Houston, Tex, USA, 1993.

[20] G. A. Yukl, Leadership in Organization, Prentice Hall, Englewood Cliffs, NJ, USA, 2nd edition, 1989.

[21] J. L. Nkata, Emerging Issues in Education Management in Developing Countries in The 21st Century, Masah Publishers, Kampala, Uganda, 2005.

[22] L. Lambert, "Shifting conceptions of leadership: towards a redefinition of leadership for the twenty first century," in Handbook of Educational Leadership and Management, pp. 515, Pearson Education, London, UK, 1999.

[23] C. O. Oyetunyi, The relationship between leadership style and school climate: Botswana secondary schools [Ph.D. thesis], University of South Africa, Pretoria, South Africa, 2006.

[24] S. Rowe, Leadership Characteristics of an Excellent Principal in Malaysia, 2007.

[25] K. Leithwood, D. Jantzi, and R. Steinback, Changing Leadership for Changing Times, Open University Press, London, UK, 1999.

[26] A. Dadey and C. Harber, Training and professional Support for Headship in Africa, Commonwealth Secretariat, Education Programme, London, UK, 1991.

[27] H. Beare, B. Caldwell, and R. Millikan, Creating an Excellent School, Routledge, London, UK, 1989.

[28] D. N. Den Hartog, J. J. Van Muijen, and P. L. Koopman, "Transactional versus transformational leadership: an analysis of the MLQ," Journal of Occupational and Organizational Psychology, vol. 70, no. 1, pp. 19-34, 1997. 

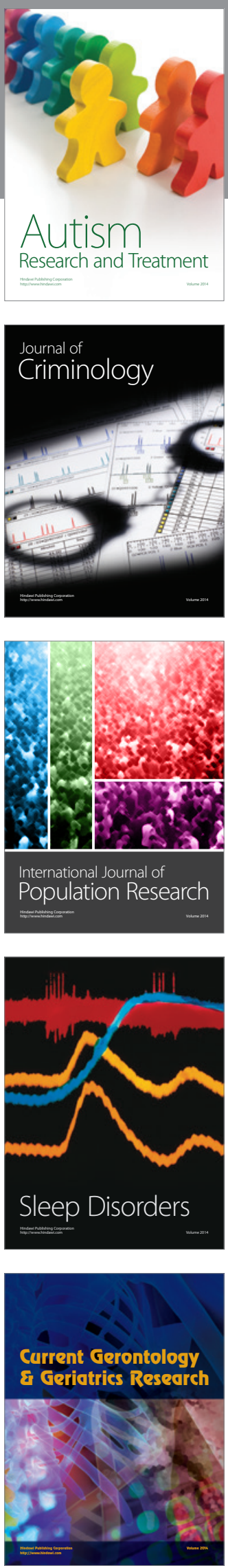
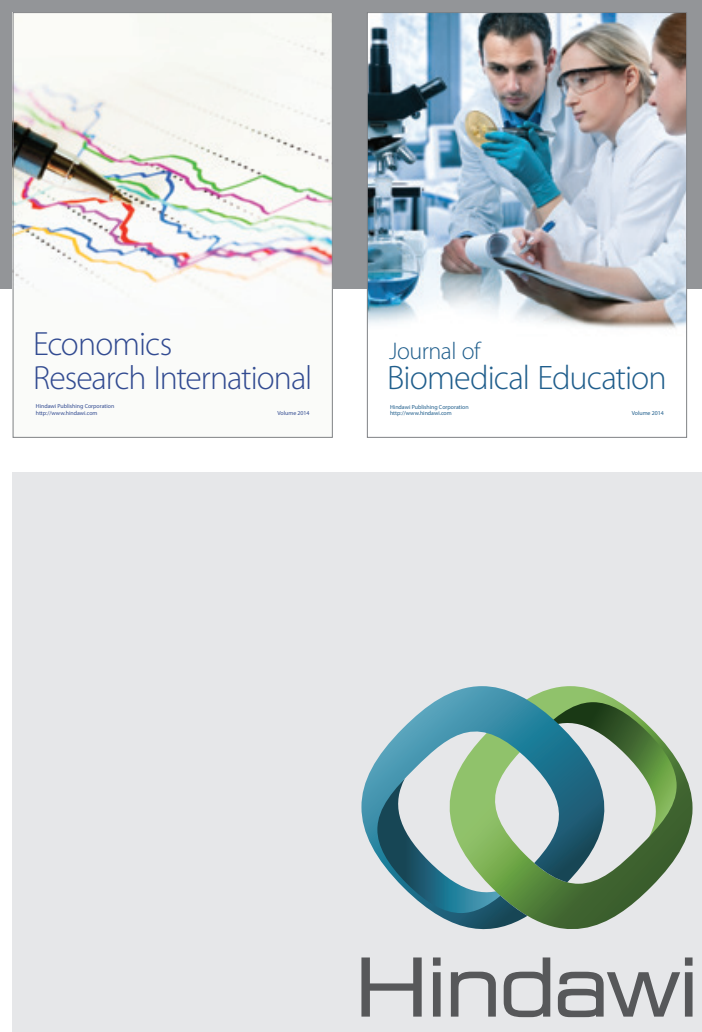

Submit your manuscripts at

http://www.hindawi.com
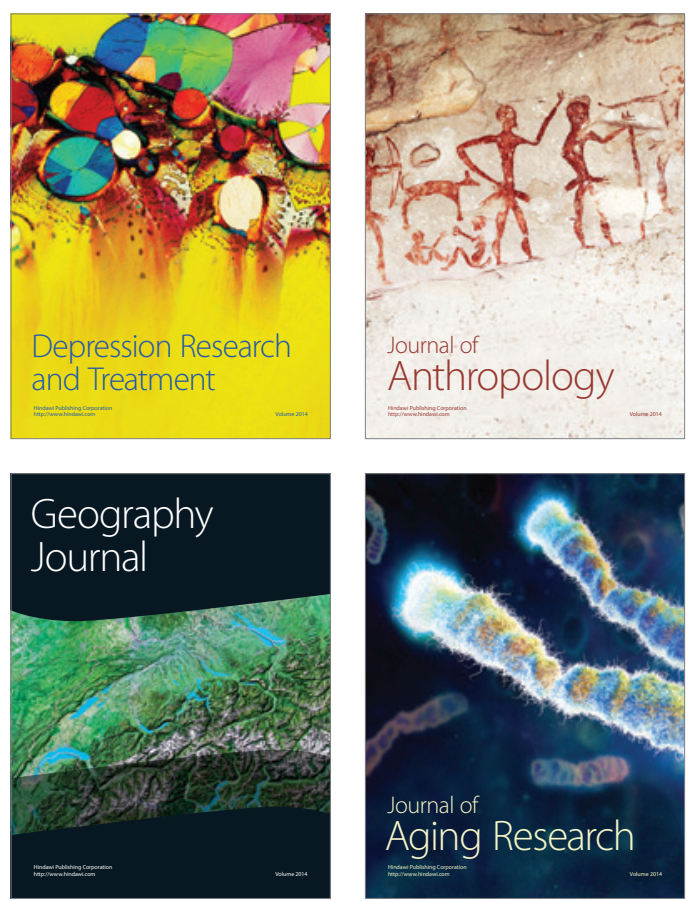
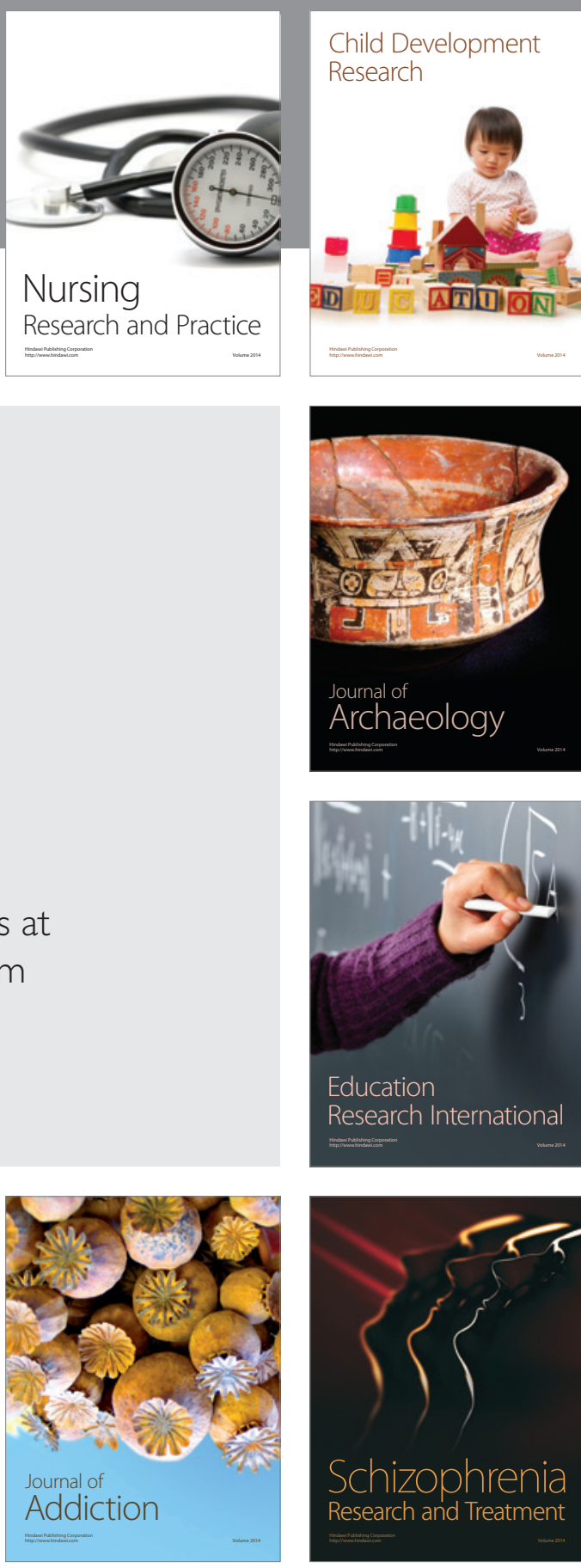

(D)
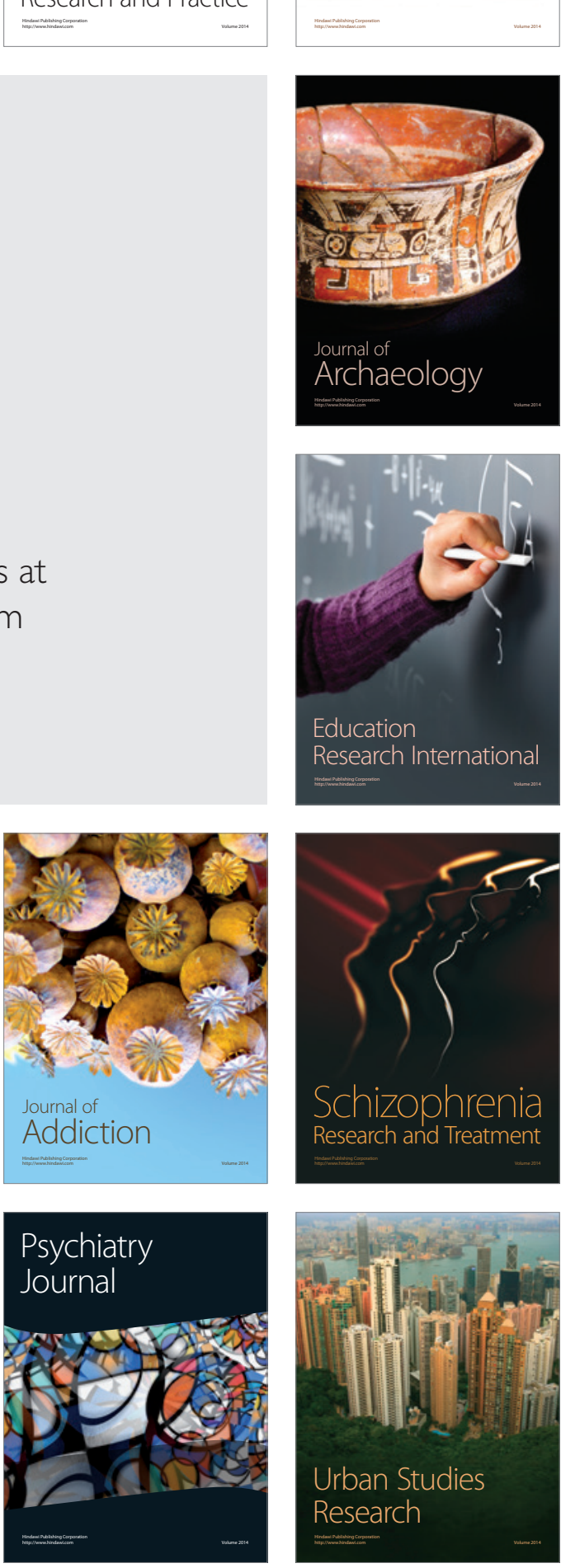